\title{
Stakeholder's financial relations and bank business management efficiency: evidence from Ukraine
}

\section{Hassan Obeid}

Ph.D. in Financial Management, Professor of Finance, Head of Finance and Accounting Department, European Business School, Paris, France

\section{Maryna Brychko}

Ph.D. in Money, Finance and Credit, Senior Lecturer, Department of Finance, Sumy State University, Ukraine

\begin{abstract}
The paper is devoted to development of evaluation of the bank business management efficiency in the system of financial relationships of their stakeholders. Non-achievement the required level of value-added banking business we divided into two groups: 1) associated with irrationality of constructing system of financial relations with their stakeholders; 2) related to the common for homogeneous group of banks problems with adaptation to national conditions of conducting banking business. In a sample of 1228 Ukrainian banks, we find that domestic banks are more adapted to the conditions of banking system although in long run foreign banks are more efficient.
\end{abstract}

Keywords: bank business management efficiency, corporate governance, Ukrainian banking system, DEA analysis.

JEL Classification: G21, G34, G14, C33.

DOI: $10.21272 /$ fmir.1(2).12-29.2017.

(C) The Authors, 2017. This article is published with open access at ARMG Publishing.

\section{Introduction}

Destabilizing processes in global and domestic financial markets, local and systemic problems in the functioning of banks that existed during the last decade led to a significant decrease in the efficiency of the banking business in Ukraine. In particular, in 2015 the banking business efficiency in Ukraine was lower than in 2005, and during 2009-2011 the banking business in fact was loss-making (the average return on assets and capital of banks for the period amounted to -2.2 and -16.0 percent, respectively). The efficiency of banks is largely determined by consistency of the management decisions, regulating organizational mechanisms of their implementation that is displayed at the efficiency of the bank business management. Within the context of ensuring efficiency of the bank business management (the growth in value added of the banking business) the congruence of economic interests of the different groups of stakeholders became particularly important. The recent work (Benson and Davidson, 2010) has also emphasized the importance of optimizing interactions with stakeholders in order to pursue shareholder value maximization or the maximization of stakeholder welfare. Considering that the interaction of the bank with the majority of stakeholders is accompanied by the movement of the cash flows, the primary task of corporate governance should be the forming an appropriate system of financial relationships with their stakeholders.

Fundamentals of the bank business management in general and banking business in particular are covered in scientific works of Aguilera (2008), Berle and Means (1932), Jensen and Meckling (1976), Schaeck and Cihák (2014), Williamson (1991), and others.

There is a vast empirical literature examining management efficiency through relationship between specific corporate governance mechanisms (i.e., risk management, managerial incentives, compensation schemes, etc.) and business performance. While empirical research does not contain any conclusive findings about direct relationships between best practices of corporate governance with business performance (Filatotchev, Toms, and Wright, 2006). This finding has no support for the hypothesized relationships between performance measures and management factors, i.e. compensation schemes (Bebchuk and Fried, 2004), ownership structure (Dalton, Daily, Certo, and Roengpitya, 2003), board independence and size (Johl, Kaur, and Cooper, 2013), etc. considered separately or taken together in a form of corporate governance ratings (Ertugrul and Hegde, 2009). Benson et al. 
(2011) also argues that positive or negative effect of governance mechanisms depends on whether the firm belongs to the consumer or industrial orientated industry and stakeholder management dimension.

Macey (1998) recommended three empirical approaching of measuring the efficiency of the different corporate governance systems: (1) by determining the level of the shareholders' control compared to their participation; (2) by measuring the willingness of entrepreneurs to make initial public offerings of stock; (3) by analysing the functioning of internal and external markets from a corporate control point of view. However, the vast number of recent studies often draws on construction a management indexes using multiple indicators of board structure and size, processes, management compensation structure, etc. or measure a particular corporate governance practice of interest. This could be viewed as second limitations to the current research designs include lack of ability to include multi-methods approaches (Aguilera and Desender, 2012).

The efficiency of the bank business management is as synthetic characteristic of not only the performance of the bank as an organizational system, but also corporate governance, which display many aspects of management, including the effectiveness of adopted and implemented certain management decisions. Therefore, the assessment process of the bank business management efficiency should be opposed to the studies of the quality of corporate governance mechanisms or the impact of the corporate governance elements on the economic efficiency, and be focus on governance outcomes, namely the increase in value added of the banking business. In this paper, the aim is two-fold. Firstly, the concept for the evaluation of the bank business management efficiency is proposed. Suggested concept disclosed the nature and peculiarities of banking business, take due account the features of forming a system of financial relations of the bank with stakeholders and based on an analysis of its financial activities. Second, is to fill this research gap by empirically evaluating bank business management efficiency in Ukraine between 2009 and 2015 using DEA modeling.

The outline of the study is as follows: In Section 2, we start by presenting the theoretical framework for efficiency computations. We therefore introduce the value-added approach of the output orientation DEA model. Third, the concept of returns to scale is defined. In Section 3, the data and empirical definitions are presented. Section 4 outlines the research methodology adopted in the study. The empirical results are presented in Section 5. In Section 6 , the conclusions and some final remarks are stated.

\section{Theoretical framework}

In this study we investigate question of bank business management efficiency based on the assumption of competition on an equal basis by comparing technical efficiency between two types of ownership. If significant difference in technical efficiency exists between two ownership groups it can be concluded that competition is not on equal basis. This demonstrates that the two types of homogeneous groups have a different access to business funding that defines the system of financial relationships with their stakeholders. This approach allows us to identify the sources of inefficiency based on differences in national stereotypes organization systems of financial relationships banks with stakeholders and their compliance with peculiarities of doing banking business in Ukraine. The decomposition of the bank business management' efficiency is achieved by dividing technical efficiency into two parts:

1) bank business management efficiency within homogeneous group of banks;

2) business management efficiency of the homogeneous group of banks within banking system of Ukraine.

Bank business management' efficiency within homogeneous group of banks $\left(E_{b b m}^{b / h g}\right)$ can be thought as the inefficiency that can be affected by managerial behavior (applying management ideology) of bank agents, within the ownership structure. Bank business management' efficiency within homogeneous group of banks represents managerial behavior in procurement, allocation, management and control of financial resources, as well as expenses, income, assets, liabilities and risks of banking activities.

Bank business management efficiency within homogeneous group of banks is concerned with procurement of financial resources by bank agents (managers) from different groups of principals in the most cost-effective basis; their utilization (delegation of financial resources to sub agent, such as investments in assets, to ensure the required level of profitability to interested parties that provided bank with financial resources based on the balance of their interests); formation and implementation of prudent dividend policy and other issues of the banks' corporate governance. 
Business management efficiency of the homogeneous group of banks within banking system of Ukraine $\left(E_{b b m} \mathrm{hg} / \mathrm{bs}\right)$ can be thought of as that part of efficiency measure that reflects different systems of financial relationships with their stakeholders. Thus, it means how banks of homogeneous group adapted to the conditions of doing banking business in Ukraine, particularly but not exclusively, the model of corporate governance reflected in decision-making, bank's response to internal and external stresses, conflicts, legal, organizational changes, etc.

Since the intention is to define reasons of inefficiency, a decomposition of the bank business management' efficiency has been carried out. The start matter to be considered with respect to the decomposition is the homogeneous groups' development. In fact, managerial decision-making of banks which belong to the same homogeneous group are similar in setting up system of financial relationships with their stakeholders.

Homogeneous groups can be distinguished by various characteristics that relate to the financial relationships with stakeholders, including: the residency equity (banks with foreign and domestic capital), ownership (public, private, cooperative, mixed banks), a territorial basis (international, national, regional banks), the nature of (universal and specialized banks), a major customer (banks that target specific types of customers: people, pensioners, small business, etc.).

Thus, Grosskopf and Valdmanis (1987) examined efficiency of individual hospitals by identifying the efficient frontier for public and not-for-profit hospitals (NFP). Their findings reflect differences in quality of care, depending on the type of ownership. Similar studies have also been conducted for the Sweden, US (Howland and Rowse, 2006; Sherman and Rupert, 2006), Taiwan (Kostyuk, Lin, and Omet, 2011), Russia (Karas, Schoors and Weill, 2010) and the European Union (Gaganis et al, 2009; Månsson, 2003; Noulas, Glaveli, and Kiriakopoulos, 2008). This study is a continuation of Månsson (2003) works, according to which banks are divided according to the residency of equity. This statement is based on differences in efficient frontiers of banks operating in Ukraine, from the perspective of the distance between the culture of countries, methods and patterns of organization of the system of financial relationships with banks' stakeholders, and what is more bank's business management and corporate governance.

According to the residence of equity banks can be divided into two groups: banks, under the control of national ownership, and those controlled by foreign owners. Determining the degree of participation of foreign investors in equity of Ukrainian banks, it should be noted that most banks, coming from abroad, prefer a controlling stake. Thus, further in our study, banks with foreign equity (banks under the full control of the foreign investor) are banks in which foreign investor take a majority stake (shareholding of more than 50 per cent of a bank's equity capital). Also among foreign banks, we exclude banks if the residency of equity is Cyprus or other offshore area, including the Virgin Islands (UK).

First, overall bank business management' efficiency, which in the existing literature viewed as "technical efficiency", can be illustrated as the distance between the bank under evaluation $(B)$ and the reference point (efficient reference bank of the total sample on the efficient frontier $(E)$ ) in Figure 1 and can be calculated as the distance $\|O B\| /\|O E\|$. Second, by computing a measure of bank business management' efficiency but only using one type of residency equity, i.e., banks controlled under foreign or domestic capital in the reference set, a measure of bank business management' efficiency within homogeneous group of banks $\left(E_{b b m}^{b / h g}\right)$ is obtained. $E_{b b m}^{b / h g}$ can be calculated as the distance $\|O B\| /\|O A\|$, and is illustrated as the distance between the bank under evaluation $(B)$ and the reference point (efficient reference bank of the separate reference set on the efficient frontier $(A)$ ) in Figure 2. Third, a measure of business management' efficiency of the homogeneous group of banks within banking system of Ukraine $\left(E_{b b m}^{h g} / b s\right)$ can be obtained by a radial comparison between the separate reference set $(A)$ and the pooled reference set $(E)$. The calculation is shown in equation 1.

$\frac{\left(\frac{\|O B\|}{|| 0 A||}\right)}{\left(\frac{\| 0 A||}{|| 0 E \mid}\right)}=\left(\frac{|| 0 B||}{|| 0 E||}\right)$

This means that bank business management' efficiency can be decomposed as: 
$E_{b b m}=E_{b b m}^{b / h g} \times E_{b b m}^{h g / b s}$

To be able to identify the reasons of inefficiency, the above framework suggests three different computations, with respect to the selection of a data set:

Computation 1: Efficiency calculated by using the pooled data set, i.e. observations from both banks with foreign or domestic capital.

Computation 2: Efficiency calculated by using the separate data set, i.e. only foreign controlled banks.

Computation 3: Efficiency calculated by using the separate data set, i.e. only banks with domestic capital.

For each computation, two different models will be calculated: one imposing constant return to scale, i.e. longrun efficiency; and the other imposing variable return to scale, i.e. short-run efficiency.

This figure demonstrates graphic illustration of the bank business management efficiency. Four data points $(O, A$, $B$, and $E$ ) are used to estimate the bank business management efficiency and the reserve of unused capacity under variable return to scale assumptions. Note that only one input and two outputs are considered in Figure. $B$ is a bank under evaluation; $A$ is an efficient reference bank of the separate reference set (homogeneous group of banks) on the efficient frontier; $E$ is an efficient reference bank of the pooled reference set (banking system of Ukraine) on the efficient frontier; $S S^{\prime}$ stands for a separate reference set (efficient frontier, represented by homogeneous group of banks, either banks controlled under domestic or foreign capital); $P P^{\prime}$ stands for a pooled reference set (efficient frontier, represented by the banking system of Ukraine, i.e. observations from both banks with foreign or domestic capital).

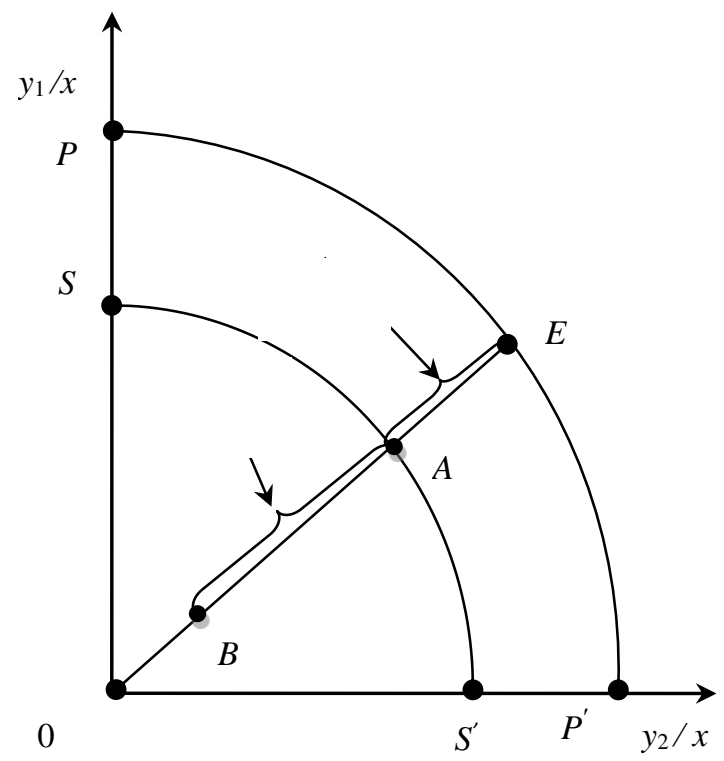

Figure 1. Graphic illustration of the bank business management' efficiency (for example, two parameters used)

By restricting the weights in the programming problem two different efficiency measures are obtained and interpreted with different scale assumptions. Depending on the banks abilities quickly to transform the internal bank management system with increasing in the scale of financial flows between the bank and its stakeholders, and complication financial relationships with them, two specifications of the model are considered: CRS-model (constant returns to scale) and VRS-model (variable returns to scale). CRS-model will be referred to as long-run efficiency. The CRS model takes into account the banks' ability during the year to adapt the mechanisms of the bank business management to quantitative and qualitative changes in the system of financial relationships with their stakeholders. The algorithm of the CRS model corresponds to the solution of the problem in general terms, as indicated in (1) and (2). In this case, any comparisons between banks of different sizes are allowed, as a constant return to scale of financial relationships with their stakeholders is considered. This implies that in the long term the bank size is largely irrelevant, and so the bank can raise any combination of input and output variables that 
characterize the construction of banks system of financial relationships with their stakeholders. Thus, bank management is apt to change the size of the share or total capital, assets or expenses which characterizes the bank profitability and sustainability in the interest of different groups of stakeholders who ensure the flow of financial flows.

VRS-model or a model of variable returns to scale will be referred to as short-run efficiency. Model VRS is assumed that transformational changes in scale of financial flows between the bank and its stakeholders are not accompanied by corresponding rapid structural changes in internal mechanisms of corporate governance. This disproportion arises due to the influence of the determinants of economies of scale (increase in flows of financial resources with stakeholders complicates the bank management and accordingly - reduce its effectiveness).

\section{Data and empirical definition}

The evaluation of the bank business management' efficiency creates several problems which arise as a result of the nature and function of banks as financial intermediaries. Under the financial intermediation approach, banks are viewed as multi-product firms that do not produce or market physical products. The specification of bank input and output variables thus constitute a major problem in the study of bank business management' efficiency, which must be addressed carefully (Colwell and Davis, 1992; Berger and Humphrey, 2000). Such specification however, will be influenced by chosen concept of the banking firm and the problem under consideration.

Depending on the particular bank's functions under investigation, a number of DEA constructions are developed: intermediation approach, production approach, operational approach, value added approach, user cost approach (Favero and Papi, 1995).

Value-added DEA approach may be more appropriate for evaluating entire financial institutions considering the system of financial relationships with their stakeholders because this approach is inclusive of interest expenses, which often account for more than one-half of banks' operating costs. Under Value-added approach, different types of credits and deposit products (savings, demand and term deposits) are considered as output parameters because their contribution to formation a significant part of the value-added. Therefore, two main components of the bank balance sheet (assets and liabilities) are viewed as outputs (Berger et al., 1987). This approach has been widely used in studies of the efficiency of banks and their branches in the Latin America and Caribbean (Carvallo and Kasman, 2005), Australian (Sathye, 2001) banking systems, French and Spanish industries (Dietsch and Lozano, 2000), and European banking systems operating under different environmental conditions (Lozano et al., 2002).

Moreover, the Value-added approach may be superior for evaluating the bank business management' efficiency in the system of financial relationships with their stakeholders, since the minimization of total costs, not just the part of costs that is related to the production process of banking products and services, is needed to maximize bank' value-added.

This study uses the Value-added approach to define bank inputs and outputs. Accordingly, in this study two inputs and tree outputs are used consisting of:

Inputs

$x_{1}=$ Interest expenses.

It represents interest payable on depositors' savings accounts and interest revenues on its loans and bond investments. An important component of a bank's interest expenses is the interest payments that it must make on its liabilities, particularly on its deposits.

Thus, it is the price that a bank charges a borrower for the use of the stakeholder's money. The following groups of stakeholders are considering as precedence in the bank's system of financial relations: entities and individuals (depositors), banks (interbank loans and deposits) and bondholders (investors). Interest expenses vary with the level of interest rates, volume of attracting resources, and structure of the deposit base, formed by the principals.

$x_{1}=$ Non-interest expenses.

It represents financial relations with bank's stakeholders' incidental to securities, foreign exchange, bank commissions and costs of running a banking business (employee salaries and benefits, rent on bank buildings, purchases of equipment). 
Employee compensation typically comprises the largest portion of bank's noninterest expenses. Non-interest expenses define bank's financial relations with their agents.

Interest and non-interest expenses relate to flows of financial resources that reflect the bank's financial relationship with their stakeholders. Interest and non-interest expenses are considered to be relevant as directly dependent on corporate governance decisions in the process of value-added bank creation. These costs are divided into direct, that directly related to the attracting financial resources (interest expenses) and indirect (non-interest expenses) that have an all-banking nature (general administrative expenses and staff costs).

\section{Outputs}

$y_{1}=$ Customer deposits.

$y_{2}=$ Net Loans (total loans less the allowance for loan losses).

Loans and deposits from customers are the main products of bank's value-added. This volume of bank loans and deposits received from various stakeholder groups providing fundamental contributions to the creation of new value added.

$y_{3}=$ Operating income.

The bank value-added is mainly measured by income that arises in this case. Operating income is the income that comes from a bank's ongoing operations. Most of a bank's operating income is generated by interest on its assets, particularly loans. Operating income consists of interest (interest on loans, securities and other interest) income and non-interest (net positive balance) income from service charges on deposit accounts, trading on the financial market, dividends, income from financial leasing, and other noninterest income. Such specification of bank output variables emphasize a prominent role of management of the bank, including corporate governance in the implementation of management decisions and the effectiveness of configuration structure that deals with the formation and implementation of value-oriented strategy of the bank. Under the value added approach of DEA model, deposits and loans are viewed as outputs because these accounts responsible to create value added bank business. The model of evaluation of the bank business management' efficiency takes into account the peculiarities of forming a system of financial relations of their stakeholders that arise when principals delegate investment and financial decisions to the agents.

\section{Research methodology}

In this paper, output-oriented DEA model used to measure three types of efficiency, namely technical efficiency of bank business management, bank business management' efficiency within homogeneous group of banks and business management' efficiency of the homogeneous group of banks within banking system of Ukraine. Depending on the optimization task of corporate governance in banks - to maximize bank value-added - DEA model and all it modifications are output-oriented. In output-oriented measure of efficiency, the objective is to achieve the maximum rate of increase that would be feasible for all outputs with the given amount of inputs. Since the main objective of good corporate governance is to manage banking activities for the interest of all stakeholder groups to ensure the procurement, allocation and reallocation of financial resources, expressed in the creation of bank value-added and ensuring harmonization of the system of financial relationships with its stakeholders. Thus, we assume bank business management' is efficient and means that it is not possible to proportional increase the output vector (bank value added reach maximum) with the given financial resources and still remains in the technology. Let there be $N$ banks use $K$ input parameters to produce $M$ output parameters. For the $i$-th bank, these data are expressed by vectors $x_{i}$ and $y_{i}$, respectively. Matrix input parameters $X(K \times N$ matrix $)$ and output parameters $Y$ $(M \times N$ matrix $)$ contain information about $N$ banks.

In general terms the objective function is defined as:

$F=\left(\varphi_{1}, \varphi_{2}, \ldots, \varphi_{N}\right) \rightarrow \max$

Formally the efficiency measure for the $i$-th bank can be calculated by solving the following mathematical programming problem:

$1 / E_{b b m}=\operatorname{Max}\left(\varphi_{i}\right)$ 
subject to:

$\sum_{i=1}^{N} \lambda_{i} \cdot y_{m i}-\varphi_{i} \cdot y_{m i}^{*} \geq 0, m=1, \ldots, M$

$x_{k i}^{*}-\sum_{j=1}^{N} \lambda_{i} \cdot x_{k i} \geq 0, k=1, \ldots, K$

$\lambda_{j} \geq 0, j=1, \ldots, N$

$\sum \lambda_{i}=1$

In above equitation, $E_{b b m}$ is the efficiency score to be calculated. Since an output framework is used, the maximum of $\varphi_{i}$, equals the largest possible increment of the output vector, such the bank still remains in the reference technology. $\varphi_{i}$ is scalar of output variables which shows by how many times the bank can increase the value added of the banking business in case of using input parameters in a technically efficient configuration; $i$ is sequential bank number $(i \in[1 ; N], N$ - observations (number of banks that have a General License of National Bank of Ukraine for the period of study)); $x_{k i}, x_{k i}^{*}$ is observed amount of input of the $k$-th type of the $i$-th bank $(k \in[1$; 2]); $y_{m i}, y_{m i}^{*}$ is an observed amount of output of the $m$-th type for the $i$-th bank ( $\left.m \in[1 ; 3]\right) ; \lambda_{i}$ is a vector of the weights (intensity variables) of the $i$-th bank to be determined by the above programming problem. Since there are no constraints for the weights $\lambda_{i}$ other than the positivity conditions in the problem (4)- (7), it imposes constant returns to scale. For allowing variable returns to scale, it is necessary to add the convexity condition for the weights $\lambda_{i}$, i.e. to include in the model (4) - (7), the restriction imposes variable return to scale assumption on the reference technology (8).

Calculated values $\varphi_{i}$ can take values greater than 1 and less than or equal to 1 . However, calculated $\varphi_{i}$ could be greater than 1, and means that even with efficient use of input parameters obtained bank business valueadded is less than potential. This indicates that the bank business value-added can be increased due to growth in productive activity without any changes in the level of the input parameters used. The efficiency score can take values $1 \leq E_{b b m}<\infty$. An efficiency score equals to 1 means that bank business management is efficient and thus located on the frontier. Defined measure of efficiency with output-oriented DEA model determines the proportion (number percent) by which bank could increase current outputs while using the same amount of inputs in order to achieve the highest level of bank business management' efficiency with the reference to other banks that function optimally. Inefficiency that can be considered as a reserve of unused capacity is then calculated as efficiency score minus 1. Reserve of unused capacity is interpreted as the generalized characteristics of the shortfall in bank business value added as a result of irrational forming of financial relationships with banks' stakeholders. Thus, the larger reserve of unused capacity bank has, the more inefficient it is. Approaching its expected value to 0 indicates the approximation of the existing system of banks' financial relationships with stakeholders to its optimum alternative. Qualitative interpretation of unused capacity reserve is shown in Table 1.

This table shows intervals for qualitative interpretation of the reserve of unused capacity. First group of banks with unused capacity reserve from 0 to $10 \%$ indicates a high level of bank business management efficiency. Unsatisfactory level of efficiency includes banks with the reserve of unused capacity equal to 10-50\%. Such banks could be deviated into two groups: banks with medium (second group) and low (third group) of efficiency with reserve of unused capacity 10-30\% and 30-50\%, respectively. Unacceptable level of bank business management efficiency has banks with the reserve of unused capacity that exceeds $50 \%$.

Table 1. Qualitative interpretation of unused capacity reserve

\begin{tabular}{|c|c|}
\hline Group of banks & Interval \\
\hline 1 & $0 \leq \theta<10 \%$ \\
\hline 2 & $10 \% \leq \theta<30 \%$ \\
\hline 3 & $30 \% \leq \theta<50 \%$ \\
\hline 4 & $50 \% \leq \theta<\infty$ \\
\hline
\end{tabular}

For banks with absolute efficiency of bank business management the reserve of unused capacity $(\theta)$ is zero. That means that bank located on efficient frontier, included to efficient reference set and being as an efficient target for each inefficient bank. However, there is a group of banks with reserve from 0 to $10 \%$. Such reserve indicates a high level of bank business management efficiency. That means bank has strong processes and practices of 
corporate governance, but along with that deficiency in some of the main components of the bank management. This level of efficiency indicates the selection and timely adjustment of the optimal strategy of the bank, banking products and operations, markets, regions and areas of action in which the bank is able to achieve a competitive edge and meet the needs of the bank in the financial, operational, technological and organizational resources.

Unsatisfactory level of efficiency includes banks with the reserve of unused capacity equal to 10-50\% and means that the bank has deficiencies in the system of corporate governance. These deficiencies may be associated with problems of the capital formation and utilization, an inconsiderate policy of risk management, asset and liability management, imperfect division of powers between bodies of bank management, insufficient protection of shareholder rights, lack of openness and transparency regarding bank activities. Unsatisfactory level of efficiency includes banks with medium and low efficiency of bank business management. The reserve of unused capacity is $10-30 \%$ and $30-50 \%$ for banks with medium and low of efficiency, respectively. The difference between these levels underpinned by the rate of changes which bank management should be taken to achieve greater levels of efficiency.

Thus, banks with medium level of bank business management efficiency have mediocre processes and practices of corporate governance, however deficiencies in some of the main components of the bank management also exists. These deficiencies can be prevented or corrected by minor changes aimed at risky asset reduction, to improve the quality of asset management, bank liquidity in order to meet the ordinary and unexpected needs of various stakeholders that ensure the flow of financial resources, to improve corporate governance code, etc.

Banks with low level of bank business management efficiency have weak processes and practices of corporate governance. These banks have significant deficiencies in some of the main components of the bank management, and require more profound changes in corporate management mechanisms and/or actions in furtherance of critical and substandard assets reduction, bank capitalization increasing and other components of the bank management.

Unacceptable level of bank business management efficiency has banks with the reserve of unused capacity that exceeds 50\%. These banks have scant processes and practices of corporate governance and significant deficiencies in most of the major components of the bank management. This inefficiency demonstrates the need for financial reorganization, increase equity to ensure capital requirements and improve creditworthiness, and therefore bank management requires fundamental changes, such as process of bank reorganization or restructuring.

\section{A. Value-added concept}

There are several concepts which usually used in the literature examining the efficiency of financial and nonfinancial institutions: the operating approach, the intermediation approach, and more recently, the revenue or (value added) approach. The intermediation approach is the most often used in academic studies of costs and efficiency in banking, since under the intermediation approach banks view as financial firms that act as an intermediary between savers and borrowers thus represent essence of the banks activity.

The present study employs the value-added approach. The concept of value-added as distinct from the concept of maximizing shareholder value, which prevailed in academic studies starting with the 1980s, is based on the process of wealth creation on the basis of balance and meet interests of different stakeholders. The value added approach in DEA proposed by Drake et al (2006). This approach identifies all accounts on both sides of the balance sheet as outputs that contribute to the generation of bank value added.

\section{B. Research method DEA}

In this study a non-parametric approach of measuring efficiency will be used. This paper apply a Data Envelopment Analysis (DEA), that has been widely used previously to analyze the efficiencies of industrial firms, booking centers, hospitals, military operations, universities and, more recently, commercial banks or bank branches. Data Envelopment Analysis calculates efficiency by solving a linear-programming problem, first proposed by Charnes, Cooper and Rhodes (1978). The framework used in DEA model originates from Farrell (1957).

The DEA model was chosen for the following reasons. First, unlike the parametric approach, DEA does not impose the specification of a particular functional form of a cost or production function or frontier. Hence, the derived efficiency scores are not functional form dependent. However, parametric approach allows for the presence of a random error term. If the data are of high quality and there are no errors, then a mandatory assumption 
of the random error term presence leads to a shift of assessment results and identified inefficiencies will be treated as statistical noise. DEA associate any deviation from the efficient frontier with inefficiency and therefore DEA may overstate the true levels of relative inefficiency (Berger and Mester, 1997). The using DEA method provides a more accurate evaluation even with small statistical noise.

Thus, applying DEA model results in:

$>$ An efficiency score (measure of each bank business management' efficiency taking into account systems of bank's financial relationships with their stakeholders, that reflects the distance from each bank to the frontier);

$>$ Decomposition of efficiency measure into Bank business management' efficiency within homogeneous group of banks and Business management' efficiency of the homogeneous group of banks within banking system of Ukraine;

$>$ Reserve of unused capacity (level of inefficiency);

$>$ An efficient frontier or frontier envelopment surface, consisting of the "best practice" banks;

$>$ An efficiency reference set or peer group, defined by a (small) subset of efficient banks "closest" to the bank under evaluation;

$>$ Efficient targets for each inefficient bank (projection of inefficient units to the "efficient frontier").

\section{Data collection and descriptive statistics}

In this study, the total number of observations is 1228 banks for the period 2009-2015. The data of 169 banks in 2009, 173 banks in 2010, 182 banks in 2011, 179 banks in 2012, over 175 banks in 2013, 2014 and 2015, respectively are included. Banks under investigation represent $98.6 \%$ of the Ukrainian banking system. The database was built on information from the annual reports of individual banks, which includes their balance sheets and income statements for the years 2009 to 2015 or 7 periods. Missing information was obtained from the National Bank Ukraine. We include banks that operated with the general licenses of the National Bank of Ukraine. Appendix A provides the descriptive statistics for the input variables of the Ukrainian banking system and separately grouped by the residence of banks equity for the period 2009-2015. According to Appendix A during 2009-2012 there was a tendency of increase in interest expense of the banking system of Ukraine. Since 2013 and during 2014 the average interest expenses decreased. The increase in interest expenses Ukraine's banking system caused primarily due to increased interest rates of deposit, prompting additional interest expense in 2009-2012. While in 2013-2014 banks have a significant savings in interest expenses due to lower interest rates on borrowed funds (15 and 10 million respectively). In part this can be explained by the fact that in order to increase the banks resource base in 2009-2010 and support their liquidity in 2011-2012 under high outflow of individuals in times of financial instability, banks set higher (incentive) interest rates term deposits, which led to an increase in additional interest expenses.

Comparing the interest expenses of domestic banks and foreign controlled banks it can be concluded that the agents of domestic banks during 2009-2015 pursued a policy of increasing the resource base by increase in interest expense on deposits formed from the principal. Foreign-controlled banks in 2013-2014 were characterized by reducing in interest expenses. Hereby foreign-controlled banks had advanced capabilities of the resource base' formation from other principals. From interest expenses management standpoint by bank agents, the process of financial relationships' management is weakly governed since the level interest expenses depends primarily on market environment (market interest rate and monetary policy of the National Bank of Ukraine). Therefore, bank agents should be directed to the resource base optimization in order to increase the share of cheaper financial resources provided by stakeholders.

During 2009-2012 there was an increase in non-interest expenses, but over the period 2013-2015 banks' agents have started to implement cost-cutting drive. Large administrative expenses could be explained by banks' willingness to use expensive qualified personnel or better equipment in order to increase greater bank business value added. In the conditions of instability, banks' agents towards revenue increasing, increased management costs regardless of whether such costs expansion stimulate further growth of bank business value added. During the period 2013-2015 there was a tendency to decrease in non-interest expenses by 15,14 and $24 \%$ respectively in 2013, 2014 and 2015 comparing to 2012. This trend was typical for both domestic and foreign-controlled banks. This might be explained by the fight against post-crisis phenomena when banks' agents tried to reduce staff and operating costs to compensate for the bank's income loss. 
In Appendix B descriptive statistics are presented for the two output parameters over the period 2009-2015 (the volume of customer deposits and net loans that act as the main sources of the bank business value added formation).

The analysis of the dynamics of deposit operations of Ukrainian commercial banks indicates that over the period 2009-2014 banks increased the volumes of deposits, and in 2015 it decreased slightly (by 14\%). In contrast to the domestic banks, the outflow of financial resources in the form of deposits from foreign-controlled banks began in 2012. Thus, the average amount of deposit resources in 2012 as compared to 2011 decreased by $4 \%$, in 2013 as compared to 2012 - by $8 \%$, in 2014 compared to the previous year - by $7 \%$, in 2015 compared to the previous year - by $19 \%$. These changes indicate a decrease in banks confidence and the lack of harmony of financial relationships with depositors as the bank' stakeholders.

Thus, based on the principle of stable resource base, banks' agents need to pay more attention to reliable financial resource sources, which primarily include time deposits. The creation of bank business value-added can be described by the dynamics of bank lending. So, after rising trend in bank lending, the peak of which reached in 2010 and 2011 was characterized by a sharp suspension of the growth rates of financial resources provided by the sub-agents.

The average balances of loans as of 01/01/2011 increased by 30 percent since this time last year, and by the end of 2011 (as of 01/01/2012), there was a significant reduction in lending (18\%) as the most negative consequences of the financial crisis, while deepening its factor. However, since 2012 has been gradually increasing financial relations with subagents and as of 01/01/2013 the average value of loans granted by the banking system of Ukraine compared to the same month of the previous year increased to $19 \%$. Dynamic change of the third output parameter (operating profit), which reflects the ability of agents to generate bank business value-added is shown in the figure 2.14 below or above. It appears from figure 2 , that the agents were increasing amounts of operating income during 2009-2015, in 2009, 2010 and 2011 at the fastest pace than before the crisis period (by 85, 71 and 15 percent, respectively, comparing to prior period). In the post-crisis period operating income increased, that could be explained as a positive trend, however the share of growth was less than 1\% in 2012 and 4\% in 2013 and 2014 respectively. Another interesting result from the figure 2 is that domestic banks meet the general dynamics of the entire banking system. However, the average value of operating income of domestic banks is less compared to the average for the banking system.

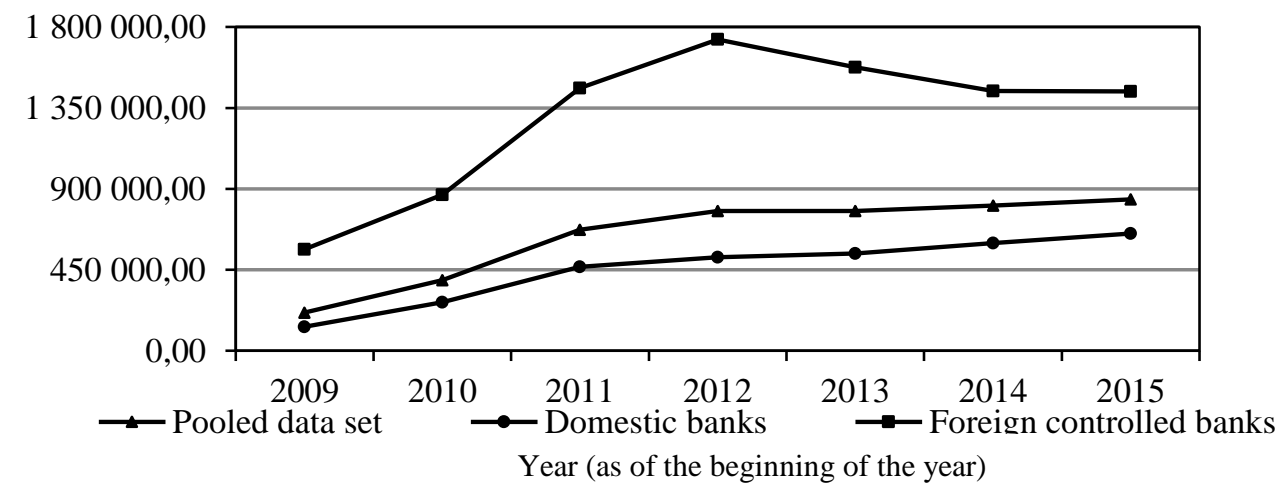

Figure 2. Dynamics of change in the average value of banks' operating profit for the period 2009-2015 (thousand UAH)

Foreign controlled banks have a positive trend in the increase of operating income before the crisis period, and its larger than the average value for the whole banking sector is 3 times in 2008 and in 2 times in 2009, 2010, 2011 respectively. Since 2012, operating income decreased by 9 and 8\% respectively in 2012 and 2013, and as of 01/01/2014 amounted to UAH 1441606.95 thousand, and reached the level of 2010. Thus, the bank agents should seek that share of operating profit tend to $100 \%$, and the rate of growth compared to the previous period was rhythmical that could indicate a positive trend in bank business value added growth.

\section{Empirical results/analysis}

\section{A. Bank business management' efficiency (technical efficiency)}

In figures 3 and 4 are presented empirical results for the first compilation, i.e. using the pooled data set concerning bank business management efficiency (technical efficiency). The analysis of the pooled data set concerning bank 
business management' efficiency taking into account systems of bank's financial relationships with their stakeholders shows that a rather large amount of inefficiency exists, both in the long (CRS) and the short (VRS) run, i.e. to increase output parameters that form the value-added banking business seems possible given resources that are used in its creation. According to conducted research in 2008-2009 banks were increasing volume of transactions that resulted in sufficiently high efficiency of bank business management, ss. 0.83 percent for the long-run model (CRS) and 0.47 percent for the short-run model (VRS) at the end of 2009. Considering the high level of public confidence in banks by households and businesses as stakeholders during 2008-2009, banks costs involved in forming a system of financial relationships with them were minor.

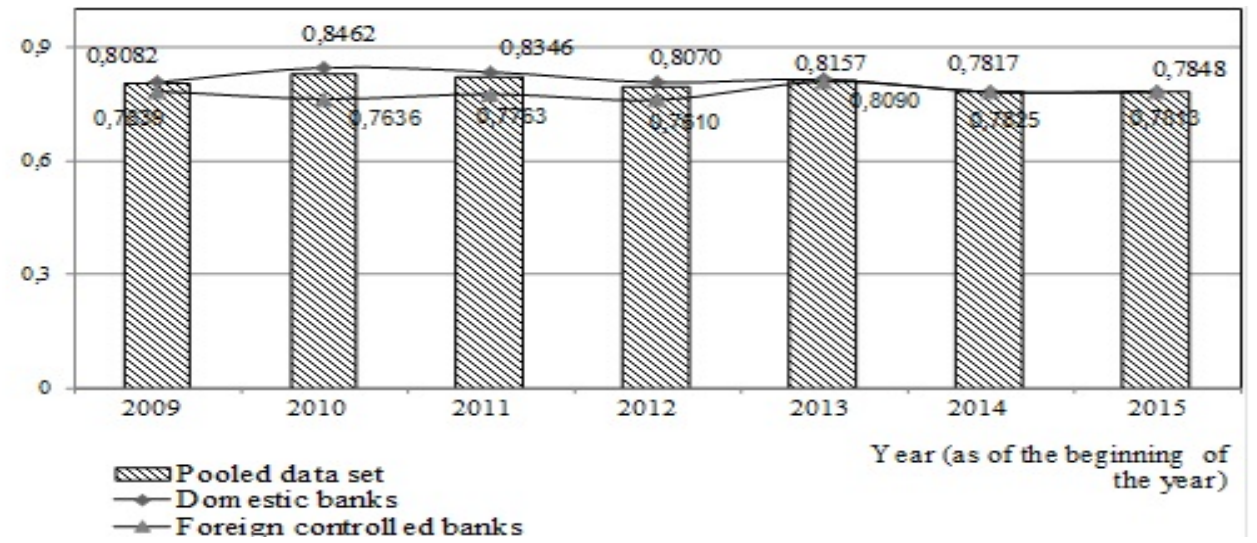

Figure 3. Value of bank business management' efficiency obtained for the model DEACRS for the period 2009-2015

In 2011 banks reached the maximum amount of inefficiency, i.e. one minus efficiency score, is 0.73 percent for the short-run model (VRS) and 0.20 percent for the long-run model (CRS) that shows the inability of most banks to neutralize exacerbation and inconformity of the economic interests of individual groups of banks' stakeholders during the crisis. The level of bank business management efficiency was contingent on stability of financial relationships with the parent bank, the National Bank of Ukraine, public authorities, regular clients and investors who have remained loyal to the bank, even in times of crisis.

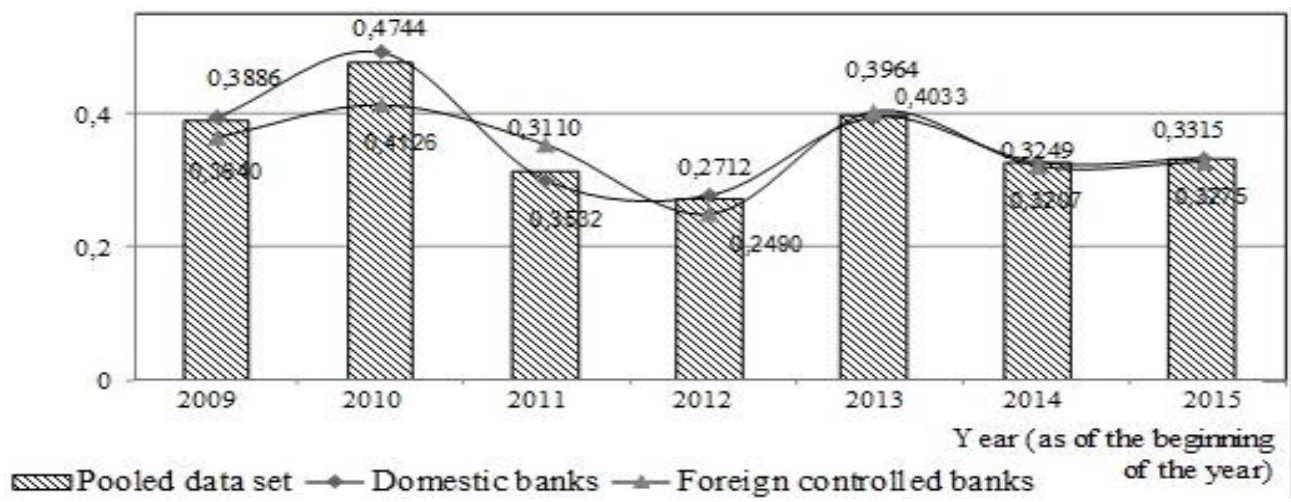

Figure 4. Value of bank business management' efficiency obtained for the model DEAvrs for the period 2009-2015

In 2012, due to introduction anti-crisis stabilization programs in majority of banks and client-oriented marketing, banks reviewed and optimized financial relationships with their stakeholders, that allowed them increase the efficiency to 0.81 percent (model CRS) and 0.40 percent (model VRS). In 2013-2015 there were negative trends in the economy as a whole and the banking system in particular, the financial condition of a number of parent banks began to deteriorate, and the state of public finances characterized by recession. This has led to significant changes in the existing systems financial relationships banks with their stakeholders and respectively to decreasing bank business management efficiency to 0.78 percent (model CRS) and 0.32 percent (model VRS). In the limited financial resources environment occurred compression interbank credit market to a small number of players, and became strategically important financial relations with the state and the National Bank of Ukraine.

In Table 2 (see in Appendix) summary statistics are presented for the first computation in the context of critical amount of inefficiency and the number of absolutely the efficient banks ("best practice" banks). 
This table reports the summary statistics on bank business management efficiency for the full samples from 2009 to 2015. The table shows the minimum and maximum efficiency score, as well as number of absolutely efficient banks and their percentage to the entire banking system of Ukraine. The sample covers 169 banks in 2009, $173-$ in 2010, 182 - in 2011, 179 - in 2012, and 175 - in 2013, 2014 and 2015.

The mean efficiency score of banks business management in Ukraine is 78-85 percent in short run. In order to assess non-optimal operating conditions the analysis of banks business management efficiency in long run were conducted. The mean efficiency score is $25-47$ percent for long run restricted model. It is also necessary noted that the analysis leads to the conclusion that commercial banks operating in Ukraine are at the same level of efficiency along with banks in Eastern Europe. Thus, Ukrainian banking system complies with the standards of countries with transition economies, where the average efficiency of banks are in the range of $70 \%$.

Among the commercial banks with the efficient bank business management that located on the best practice frontier were banks with different groups of assets. As at 01/01/2009 only domestic banks were located on the long run best practice frontier. During the period under investigation, the number of banks with business management efficiency ranges from 3 to 6 percent of the entire banking system of Ukraine. The number of banks that located on the short run best practice frontier was from 16 to 26 percent of the entire banking system of Ukraine for the analyzed period. Among them are largest domestic and foreign controlled banks.

As far apart as possible from the best practice frontier were located captive banks that operate exclusively on some principals, their owners. Among the banks with ineffective bank business management were also banks controlled by foreign capital. This conclusion is different from most international studies. This could serve as a confirmation of the specificity of the Ukrainian banking sector and inefficiency selected patterns strategy of the bank, under its corporate governance and organization that built entirely on the principles recommended by foreign organizations and international best practices, which are sometimes poorly fit in Ukrainian reality. Detailed analysis of the bank business management efficiency allows to confirm the general trends of the banking business in the world. The greatest scores of bank business management inefficiency reached in 2011.

\section{A. Bank business management' efficiency within homogeneous group of banks}

In figures 5 and 6 are presented empirical results for the second and third compilations, i.e. using the separate data set concerning bank business management efficiency within homogeneous group of banks. Even for bank business management' efficiency within homogeneous group of banks, the results show rather large amounts of inefficiency. Since bank business management' efficiency within homogeneous group compares banks within controlling ownership group, a large amount of inefficiency indicates inefficient managerial behavior. It appears from the figure 5 that bank business management' efficiency within homogeneous group of foreign controlled banks is higher compared to the same period for homogeneous group of domestic banks for the long run model (CRS). The inefficiency score for homogeneous group of foreign controlled banks came within a range of 9 percent to 18 percent, and 10 percent to 19 percent for homogeneous group of domestic banks. This seems to be driven by the access of foreign controlled banks to the capital of parent banks and foreign markets, which is reflected in the system of financial relationships with their stakeholders. In the post-crisis period, banks of both homogeneous groups showed a similar trend to change the bank business management efficiency, as followed similar principles to the formation of a system of financial relationships with their stakeholders.

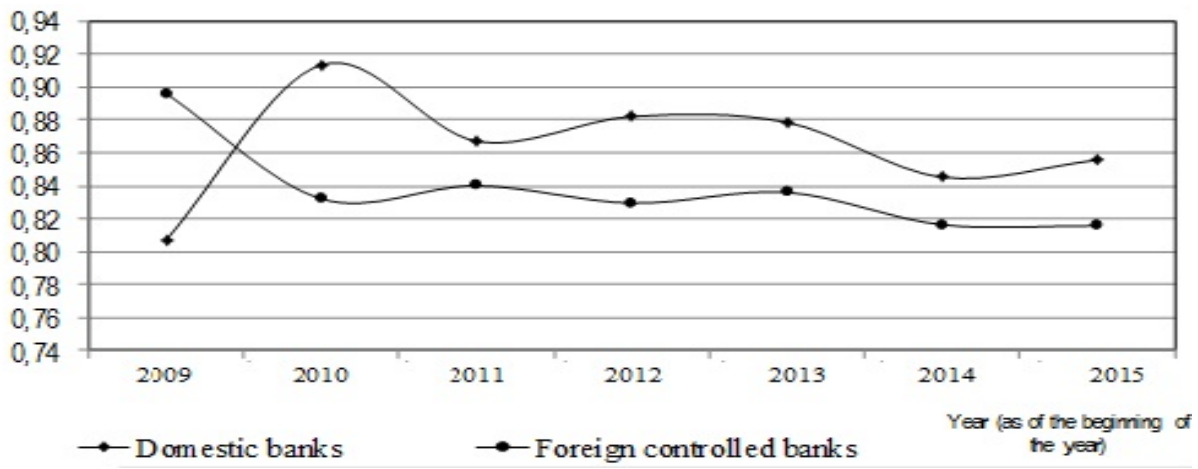

Figure 5. Value of bank business management' efficiency within homogeneous group for the period 2009-2015 by model DEACRS 
From the figure 6 below we can see the critical inefficiency of managerial decisions. Special attention should improve the efficiency of domestic banks in the post-crisis period, unlike banks controlled by foreign capital.

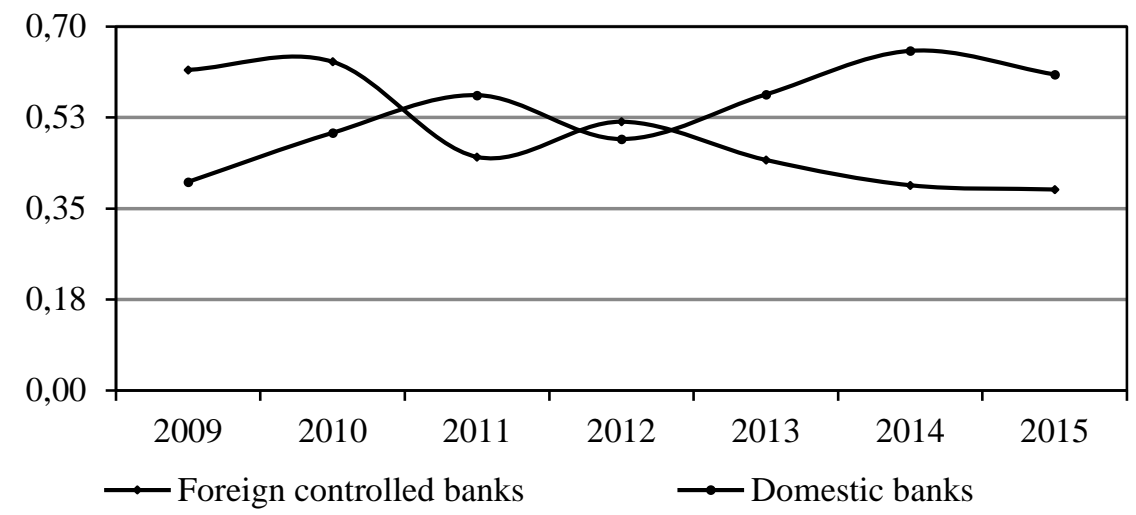

Figure 6. Value of bank business management' efficiency within homogeneous group for the period 2009-2015 by model DEAVRS

During the crisis, when there is so-called "reallocation of opportunities" the agents of domestic banks were unable adequately respond to relevant changes of external environment. Banks controlled by foreign capital, by contrast, reached the highest scores of managerial efficiency. This can be explained by the fact that making managerial decisions was reinforced by stable financial relations with agents of the bank expressed in accessibility to larger financial resources from abroad. In the post-crisis period the financial position of headquarters began to deteriorate, and therefore financial relations of the principal and the agent began to change, and accordingly have changed and the flow of financial resources from banks, which was reflected in the deterioration of efficiency. According to the figure 6 for the model DEAvRs foreign controlled banks are less efficient compared to domestic banks in post crisis period. This can be explained by the fact that agents of foreign controlled banks make decisions with limited financial resources, because the interbank market shrank to a small number of players, supported by refinancing loans from the National Bank of Ukraine based on the long history of relations. That's why agents of banks controlled by foreign capital had to operate in more severe conditions. Thus, evaluation of bank business management' efficiency within homogeneous group of banks using the above described models are based on a system of bank management in different institutional settings that is displayed in the coordinated activities of banks agents and sustainable development of financial relations with their stakeholders.

\section{B. Business management' efficiency of the homogeneous group of banks within banking system of Ukraine}

Harmonization of financial relationships with banks stakeholders to the current conditions of the banking business in Ukraine should ensure coordination of the corporate governance system with other bank management systems in order to achieve maximization of value added of banking business. One measure of short and one measure of long run efficiency have been computed (results presented on figures 7-8).

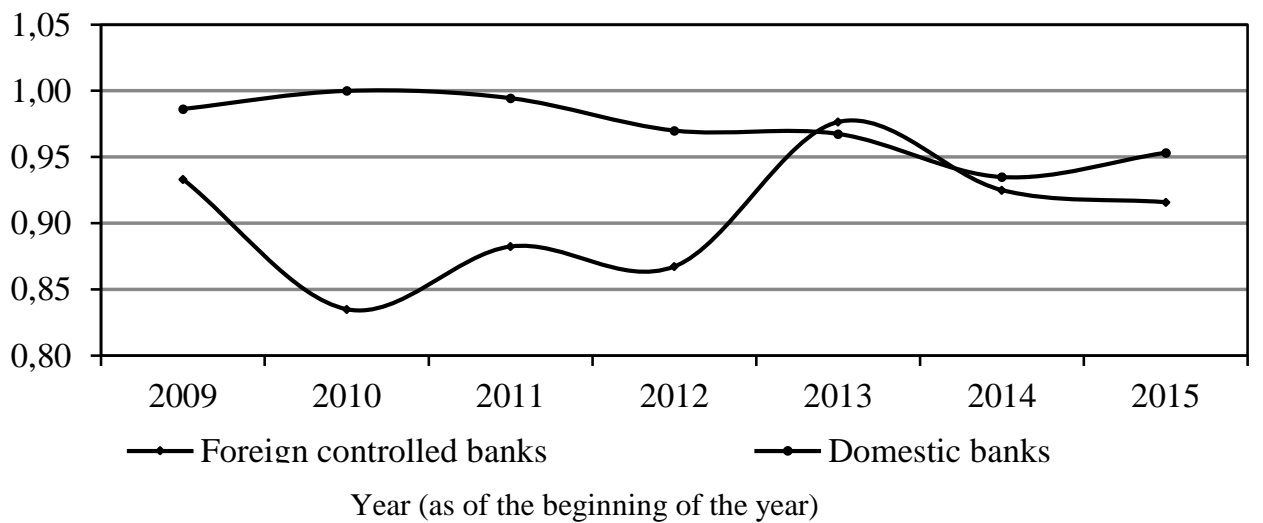

Figure 7. Business management' efficiency of the homogeneous group of banks within banking system of Ukraine for the period 2009-2015 by model DEACrs 
The calculations shown in Figure 7 (model CRS) domestic banks were better adapted to the conditions of the banking business in Ukraine than banks controlled by foreign capital. The efficiency scores for domestic banks shows a downward trend since 2010, and banks controlled by foreign capital in 2010-2013 - upward, and in 20132015 - downward. This fact can be explained in terms of the adequacy of corporate governance system to national stereotypes functioning of commercial banks in Ukraine. Thus, numerous recommendations made by foreign experts regarding the quality of construction the corporate governance structure do not meet to the realities of functioning of commercial banks in Ukraine.

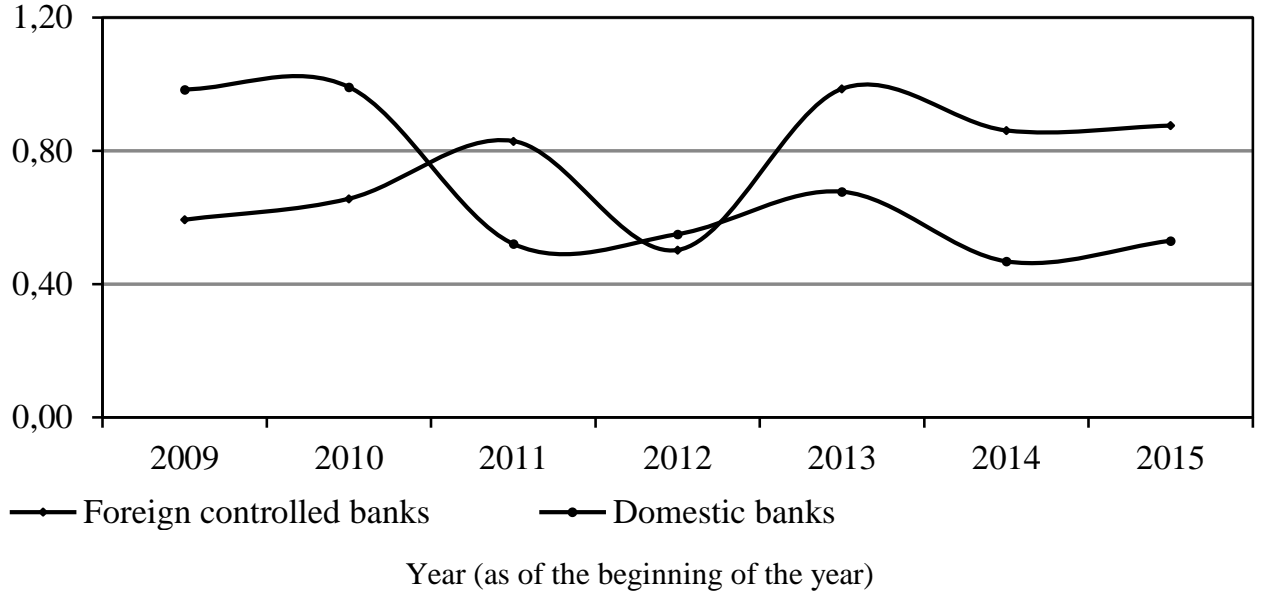

Figure 8. Business management' efficiency of the homogeneous group of banks within banking system of Ukraine for the period 2009-2015 by model DEAvrs

As can be seen from Figure 8, on average organizational efficiency (business management' efficiency of the homogeneous group of banks within banking system of Ukraine) is higher for foreign controlled banks in post crisis period. The existence of such trend shows that to date there is no universal type of forming the system of financial relationships with stakeholders that would ensure maximum efficiency; the type and configuration of the system of financial relationships principals and agents are individual for each bank and depend on numerous factors, including the composition and structural features of corporate governance.

Thus, considered models based on maximizing output parameters that are the main attributes of value added of banking business, determine for each inefficient bank target amount of growth of value added in the banking business. On average it is possible to increase the growth of value added of banking business by 45-60 percent for variable returns to scale and by 8-19 percent for constant returns to scale, keeping constant volume of the financial resources.

\section{Conclusion and concluding remarks}

The purpose of the study was to investigate if competition between domestic and foreign controlled banks was on equal basis. To be able to answer this question efficiency measures were calculated. It was established that management processes in banks that belong to one homogeneous group (are close by specificity of building financial relationships with banks stakeholders) have a number of common features that must be taken into account when assessing the bank business management efficiency. Homogenous groups can be distinguished according to different characteristics related to the financial relations with their stakeholders. Bank business management efficiency (technical efficiency) was decomposed into bank business management' efficiency within homogeneous group of banks and business management' efficiency of the homogeneous group of banks within banking system of Ukraine. The results indicate that in long run the foreign controlled banks have higher average bank business management efficiency within homogeneous group of banks compared to domestic banks over the period 20102015. However, domestic banks were more adapted to the conditions of the banking business in Ukraine than foreign controlled banks, although the dynamics of business management' efficiency of the homogeneous group of domestic banks within banking system of Ukraine shows a downward trend. 
1. Aguilera, R.V., I. Filatotchev, H. Gospel, and G. Jackson (2008). An organizational approach to comparative corporate governance: Costs, contingencies, and complementarities. Organization Science, 19(3), 475-492.

2. Aguilera, R.V., and K.A. Desender (2012). Challenges in the measuring of comparative corporate governance: a review of the main indices. Research Methodology in Strategy and Management, 7.

3. Bebchuk, L.A., and J.M. Fried (2004). Pay without performance: The unfulfilled promise of executive compensation. Cambridge, MA: Harvard University Press.

4. Benson, B. W., Davidson III, W. N., Wang, H. and Worrell, D. L. (2011). Deviations from Expected Stakeholder Management, Firm Value, and Corporate Governance. Financial Management, 40, 39-81.

5. Benson, B. W. and Davidson, W. N. (2010). The Relation between Stakeholder Management, Firm Value, and CEO Compensation: A Test of Enlightened Value Maximization. Financial Management, 39, 929-964.

6. Berger, A.N., T.H. Hanweck and D.B. Humphrey (1987). Competitive viability in banking: Scale, scope, and product mix economies. Journal of Monetary Economics, 20, 501-520.

7. Berger, A.N., and D.B. Humphrey (2000). Efficiency of financial institutions: international survey and directions for future research. Performance of Financial Institutions: Efficiency, Innovation, Regulation, Cambridge, UK.

8. Berle, A.A., and G.G.C. Means (1932). The modern corporation and private property, Transaction Books.

9. Carvallo, O., and A. Kasman (2005). Cost efficiency in the Latin America and Caribbean banking systems. Journal of International Financial Markets, Institutions and Money, 15, 55-72.

10. Charnes, A., W. Cooper, and E. Rhodes (1978). Measuring the Efficiency of Decision Making Units. European Journal of Operational Research, 2, 429-444.

11. Colwell, R. J., and E. P. Davis (1992). Output and productivity in banking. Scandinavian Journal of Economics, 94 Supplement, 111-129.

12. Dalton, D. R., C. M. Daily, S. Certo, and R. Roengpitya (2003). Meta-analysis of financial performance and equity: fusion or confusion? Academy of Management Journal, 46, 13-26.

13. Dietsch, M., and A. V. Lozano (2000). How the environment determines banking efficiency: A comparison between French and Spanish industries. Journal of Banking and Finance, 24, 985-1004.

14. Drake, L., M J B Hall, and R. Simper (2006). The impact of macroeconomic and regulatory factors on bank efficiency: a non-parametric analysis of Hong Kong's banking system. Journal of Banking and Finance, 30 (5), 1443-1466.

15. Ertugrul, M. and Hegde, S. (2009). Corporate Governance Ratings and Firm Performance. Financial Management, 38, 139-160.

16. Farell, M. (1957). The Measurement of Productive Efficiency. Journal of the Royal Statistical Society, 120 (3), 253-291.

17. Favero, C., and L. Papi (1995). Technical Efficiency and Scale Efficiency in the Italian Banking Sector: A Non-parametric Approach. Applied Economics, 27, 385-395.

18. Filatotchev, I., S. Toms, and M. Wright (2006). The firm's strategic dynamics and corporate governance lifecycle. International Journal of Managerial Finance, 2(4), 256-279.

19. Gaganis, C., A. Liadaki, M. Doumpos, and C. Zopounidis (2009). Estimating and analyzing the efficiency and productivity of bank branches: Evidence from Greece. Managerial Finance, 35(2), 202-218.

20. Grosskopf, S., and V. Valdmanis (1987). Measuring Hospital Performance. A Non-Parametric Approach, Journal of Health Economics, 89-107.

21. Howland, M., and J. Rowse (2006). Measuring Bank Branch Efficiency Using Data Envelopment Analysis. Managerial and Implementation Issues, 44(1), 49-63.

22. Jensen, M.C. (2000). A Theory of the Firm: Governance, Residual Claims, and Organizational Forms. Cambridge et al.: Harvard University Press, 678.

23. Jensen, M.C. (1986). Agency Costs of Free Cash Flow, Corporate Finance and Takeovers. American Economic Review, 76, 323-329.

24. Jensen, M.C., and W.H. Meckling (1976). Theory of the Firm: Managerial Behavior, Agency Costs and Ownership Structure. Journal of Financial Economics, 3, 305.

25. Johl, S. K., S. Kaur, and B.J. Cooper (2013). Board characteristics and firm performance: evidence from Malaysian public listed firms. Journal of Economics, Business and Management, 3(2). 
26. Karas, A., K. Schoors, and L. Weill (2010). Are private banks more efficient than public banks? Economics of Transition, 18, 209-244.

27. Kostyuk, A., M. Lin, and G. Omet (2011). "Banking system of Taiwan", Euroasian perspectives of the banking systems development, Virtus Interpress, 167.

28. Lozano, V.A., J.A. Pastor and J.M. Pastor (2002). An efficiency comparison of European banking systems operating under different environmental conditions. Journal of Productivity Analysis, 18, 59-77.

29. Månsson, J. (2003). How Can We Use the Result from a DEA Analysis? Identification of Firm-relevant Reference Units. Journal of Applied Economics, 6/1, 157-175.

30. Macey, J. (1998). Measuring the Effectiveness of Different Corporate Governance Systems: Toward a More Scientific Approach. Journal of Applied Corporate Finance, 10, 16-25.

31. Noulas, A., N. Glaveli, and I. Kiriakopoulos (2008). Investigating cost efficiency in the branch network of a Greek bank: an empirical study. Managerial Finance, 34(3), 160-171.

32. Sathye, M. (2001). X-efficiency in Australian banking: An empirical investigation. Journal of Banking and Finance, 25, 613-630.

33. Schaeck, K. and Cihák, M. (2014). Competition, Efficiency, and Stability in Banking. Financial Management, 43, 215-241.

34. Sherman, H.D., and T.J. Rupert (2006). Do bank mergers have hidden or foregone value? Realized and unrealized operating synergies in one bank merger. European Journal of Operational Research, 168(1), 253-268.

35. Williamson, O.E. (1991). Comparative economic organization: The analysis of discrete structural alternatives. Administrative Science Quarterly, 269-296.

\section{Appendix A}

Table 2. Summary statistics on bank business management efficiency using pooled data set as reference for the period 2009-2015

\begin{tabular}{|c|c|c|c|c|c|c|}
\hline Year & Efficiency & Maximum & $\begin{array}{l}\text { Number of absolutely ef- } \\
\text { ficient banks (units of ob- } \\
\text { servation), banks }\end{array}$ & $\begin{array}{l}\text { Percentage to the } \\
\text { entire banking } \\
\text { system, } \%\end{array}$ & Minimum & $\begin{array}{l}\text { Number of observa- } \\
\text { tions used as } \\
\text { a reference, banks }\end{array}$ \\
\hline \multirow{2}{*}{2009} & $\begin{array}{l}\text { Short run } \\
\text { (DEAvRs) }\end{array}$ & 1.000 & 39 & 23 & 0.076 & 169 \\
\hline & $\begin{array}{l}\text { Long run } \\
\text { (DEACRs) }\end{array}$ & 1.000 & 7 & 4 & 0.156 & 169 \\
\hline \multirow{2}{*}{2010} & $\begin{array}{l}\text { Short run } \\
\text { (DEAvRs) }\end{array}$ & 1.000 & 40 & 23 & 0.110 & 173 \\
\hline & $\begin{array}{l}\text { Long run } \\
\text { (DEACRs) }\end{array}$ & 1.000 & 11 & 6 & 0.117 & 173 \\
\hline \multirow{2}{*}{2011} & $\begin{array}{l}\text { Short run } \\
\text { (DEAvrs) }\end{array}$ & 1.000 & 31 & 17 & 0.091 & 182 \\
\hline & $\begin{array}{l}\text { Long run } \\
\text { (DEACRs) }\end{array}$ & 1.000 & 6 & 3 & 0.157 & 182 \\
\hline \multirow{2}{*}{2012} & $\begin{array}{l}\text { Short run } \\
\text { (DEAvrs) }\end{array}$ & 1.000 & 29 & 16 & 0.011 & 179 \\
\hline & $\begin{array}{l}\text { Long run } \\
\text { (DEACRs) }\end{array}$ & 1.000 & 5 & 3 & 0.036 & 179 \\
\hline \multirow{2}{*}{2013} & $\begin{array}{l}\text { Short run } \\
\text { (DEAvrs) }\end{array}$ & 1.000 & 45 & 26 & 0.041 & 175 \\
\hline & $\begin{array}{l}\text { Long run } \\
\text { (DEACRs) }\end{array}$ & 1.000 & 7 & 4 & 0.126 & 175 \\
\hline \multirow{2}{*}{2014} & $\begin{array}{l}\text { Short run } \\
\text { (DEAvrs) }\end{array}$ & 1.000 & 33 & 19 & 0.034 & 175 \\
\hline & $\begin{array}{l}\text { Long run } \\
\text { (DEACRs) }\end{array}$ & 1.000 & 7 & 4 & 0.077 & 175 \\
\hline \multirow{2}{*}{2015} & $\begin{array}{l}\text { Short run } \\
\text { (DEAvrs) }\end{array}$ & 1.000 & 28 & 16 & 0.065 & 175 \\
\hline & $\begin{array}{l}\text { Long run } \\
\text { (DEACRS) }\end{array}$ & 1.000 & 9 & 5 & 0.108 & 175 \\
\hline
\end{tabular}


Table I. The descriptive statistics for the two input variables over the period 2009-2015

\begin{tabular}{|c|c|c|c|c|c|}
\hline & Computation & Minimum & Maximum & Mean & Standard deviation \\
\hline \multicolumn{6}{|c|}{2009} \\
\hline \multirow{3}{*}{$x_{1}$} & Pooled data set & 0,0 & 1856867,0 & 98446,95 & 229786,4 \\
\hline & Foreign controlled banks & 0,0 & 1856867,0 & 70558,33 & 189855,7 \\
\hline & Banks with domestic capital & 193,0 & 1173490,0 & 222596,3 & 334034,5 \\
\hline \multirow{3}{*}{$x_{2}$} & Pooled data set & 44,0 & 1932894,0 & 95450,78 & 226758,8 \\
\hline & Foreign controlled banks & 44,0 & 898154,0 & 57903,33 & 117527,7 \\
\hline & Banks with domestic capital & 7020,0 & 1932894,0 & 262597,50 & 435335,1 \\
\hline \multicolumn{6}{|c|}{2010} \\
\hline \multirow{3}{*}{$x_{1}$} & Pooled data set & 0,00 & 350,0 & 2946415,0 & 165395,20 \\
\hline & Foreign controlled banks & 0,00 & 528,0 & 2946415,0 & 112321,60 \\
\hline & Banks with domestic capital & 72192,00 & 350,0 & 1970757,0 & 367369,80 \\
\hline \multirow{3}{*}{$x_{2}$} & Pooled data set & 292,00 & 761,0 & 3882005,0 & 178129,00 \\
\hline & Foreign controlled banks & 292,00 & 761,0 & 3882005,0 & 117574,80 \\
\hline & Banks with domestic capital & 19737,00 & 8998,0 & 2616176,0 & 408571,70 \\
\hline \multicolumn{6}{|c|}{2011} \\
\hline \multirow{3}{*}{$x_{1}$} & Pooled data set & 376,0 & 5066715,0 & 279220,20 & 629284,1 \\
\hline & Foreign controlled banks & 376,0 & 5066715,0 & 202158,70 & 547941,0 \\
\hline & Banks with domestic capital & 1110,0 & 2946313,0 & 571243,0 & 816151,75 \\
\hline \multirow{3}{*}{$x_{2}$} & Pooled data set & 4923,0 & 8406981,0 & 336011,40 & 873457,0 \\
\hline & Foreign controlled banks & 4923,0 & 8406981,0 & 219630,60 & 775770,5 \\
\hline & Banks with domestic capital & 15299,0 & 4534428,0 & 777033,60 & 1074120,0 \\
\hline \multicolumn{6}{|c|}{2012} \\
\hline \multirow{3}{*}{$x_{1}$} & Pooled data set & 0,0 & 6954305,0 & 365125,80 & 873020,2 \\
\hline & Foreign controlled banks & 0,0 & 6954305,0 & 257387,50 & 767009,6 \\
\hline & Banks with domestic capital & 0,0 & 3788940,0 & 764891,40 & 1110067,0 \\
\hline \multirow[t]{3}{*}{$x_{2}$} & Pooled data set & 1983,0 & 9557341,0 & 591092,10 & 1424041,0 \\
\hline & Foreign controlled banks & 1983,0 & 9557341,0 & 377841,10 & 1129033,0 \\
\hline & Banks with domestic capital & 10303,0 & 8355874,0 & 1382366,00 & 2028847,0 \\
\hline \multicolumn{6}{|c|}{2013} \\
\hline \multirow{3}{*}{$x_{1}$} & Pooled data set & 17,0 & 8429808,0 & 350909,6 & 899645,4 \\
\hline & Foreign controlled banks & 887,0 & 8429808,0 & 263282,7 & 878944,1 \\
\hline & Banks with domestic capital & 17,0 & 3191294,0 & 646650,5 & 916698,8 \\
\hline \multirow{3}{*}{$x_{2}$} & Pooled data set & 4239,0 & 8605150,0 & 501343,2 & 1240158,0 \\
\hline & Foreign controlled banks & 4239,0 & 8605150,0 & 292713,4 & 985013,2 \\
\hline & Banks with domestic capital & 11103,0 & 7404905,0 & 1205469,0 & 1693798,0 \\
\hline \multicolumn{6}{|c|}{2014} \\
\hline \multirow{3}{*}{$x_{1}$} & Pooled data set & 129,0 & 8846283,0 & 340032,1 & 891095,0 \\
\hline & Foreign controlled banks & 129,0 & 8846283,0 & 281211,8 & 934928,5 \\
\hline & Banks with domestic capital & 2413,0 & 2399643,0 & 520596,5 & 720451,8 \\
\hline \multirow{3}{*}{$x_{2}$} & Pooled data set & 2611,0 & 11939890,0 & 503898,0 & 1372706,0 \\
\hline & Foreign controlled banks & 2611,0 & 11939890,0 & 336049,4 & 1259968,0 \\
\hline & Banks with domestic capital & 12912,0 & 7630068,0 & 1019154,0 & 1579419,0 \\
\hline \multicolumn{6}{|c|}{2015} \\
\hline \multirow{3}{*}{$x_{1}$} & Pooled data set & 0,0 & 10104859,0 & 389937,1 & 1003721,0 \\
\hline & Foreign controlled banks & 0,0 & 10104859,0 & 319634,8 & 1047335,0 \\
\hline & Banks with domestic capital & 3877,0 & 2908426,0 & 612560,8 & 822935,1 \\
\hline \multirow{3}{*}{$x_{2}$} & Pooled data set & 1752,0 & 11002533,0 & 423279,0 & 1149084,0 \\
\hline & Foreign controlled banks & 1752,0 & 11002533,0 & 303177,4 & 1134886,0 \\
\hline & Banks with domestic capital & 17250,0 & 5576787,0 & 803600,9 & 1123405,0 \\
\hline
\end{tabular}




\section{Appendix B}

Table II. The descriptive statistics for the two output parameters over the period 2009-2015

\begin{tabular}{|c|c|c|c|c|c|}
\hline & Computation & Minimum & Maximum & Mean & Standard deviation \\
\hline \multicolumn{6}{|c|}{2009} \\
\hline \multirow{3}{*}{$y_{1}$} & Pooled data set & 7523,00 & 21735198,00 & 1284807,66 & 3027104,58 \\
\hline & Foreign controlled banks & 7523,00 & 13993034,00 & 744872,99 & 1616001,64 \\
\hline & Banks with domestic capital & 28484,00 & 21735198,00 & 3688387,84 & 5663775,11 \\
\hline \multirow{3}{*}{$y_{2}$} & Pooled data set & 0,00 & 17082075,00 & 1054895,47 & 2318067,70 \\
\hline & Foreign controlled banks & 0,00 & 8440595,00 & 669388,20 & 1323828,47 \\
\hline & Banks with domestic capital & 20658,00 & 17082075,00 & 2771024,61 & 4284993,24 \\
\hline \multicolumn{6}{|c|}{2010} \\
\hline \multirow{3}{*}{$y_{1}$} & Pooled data set & 0,00 & 41694303,00 & 2485849,91 & 5987056,88 \\
\hline & Foreign controlled banks & 0,00 & 41694303,00 & 1562401,77 & 4489084,35 \\
\hline & Banks with domestic capital & 72192,00 & 37253383,00 & 6000083,11 & 9044709,71 \\
\hline \multirow{3}{*}{$y_{2}$} & Pooled data set & 292,00 & 38093592,00 & 1840399,80 & 4402629,08 \\
\hline & Foreign controlled banks & 292,00 & 38093592,00 & 1338680,18 & 3874946,43 \\
\hline & Banks with domestic capital & 19737,00 & 23011462,00 & 3749721,67 & 5672257,47 \\
\hline \multicolumn{6}{|c|}{2011} \\
\hline \multirow{3}{*}{$y_{1}$} & Pooled data set & 0,00 & 72788727,00 & 4075911,97 & 10039563,52 \\
\hline & Foreign controlled banks & 0,00 & 72788727,00 & 2538888,37 & 7898581,86 \\
\hline & Banks with domestic capital & 83047,00 & 54727538,00 & 9900422,47 & 14419148,73 \\
\hline$y_{2}$ & Pooled data set & 300,00 & 57088455,00 & 2399597,49 & 6039399,43 \\
\hline & Foreign controlled banks & 300,00 & 57088455,00 & 1768065,67 & 5491319,43 \\
\hline & Banks with domestic capital & 18172,00 & 28355149,00 & 4792770,68 & 7379082,66 \\
\hline \multicolumn{6}{|c|}{2012} \\
\hline \multirow{3}{*}{$y_{1}$} & Pooled data set & 0,00 & 74991912,00 & 4057518,37 & 10221060,98 \\
\hline & Foreign controlled banks & 0,00 & 74991912,00 & 2597262,43 & 8713912,52 \\
\hline & Banks with domestic capital & 0,00 & 48724527,00 & 9475836,45 & 13304019,01 \\
\hline \multirow{3}{*}{$y_{2}$} & Pooled data set & 0,00 & 49835285,00 & 1953273,65 & 5218036,39 \\
\hline & Foreign controlled banks & 0,00 & 49835285,00 & 1518759,40 & 5058276,25 \\
\hline & Banks with domestic capital & 1256,00 & 27667673,00 & 3565550,24 & 5548569,14 \\
\hline \multicolumn{6}{|c|}{2013} \\
\hline \multirow{3}{*}{$y_{1}$} & Pooled data set & 10696,00 & 101855171,00 & 4288779,31 & 11275463,30 \\
\hline & Foreign controlled banks & 10696,00 & 101855171,00 & 2975720,60 & 10814049,16 \\
\hline & Banks with domestic capital & 15000,00 & 43853742,00 & 8720352,45 & 11802776,77 \\
\hline \multirow{3}{*}{$y_{2}$} & Pooled data set & 9201,00 & 75182793,00 & 2511121,30 & 7076902,68 \\
\hline & Foreign controlled banks & 9201,00 & 75182793,00 & 1982328,97 & 7260225,71 \\
\hline & Banks with domestic capital & 13347,00 & 28341726,00 & 4295795,40 & 6172634,10 \\
\hline \multicolumn{6}{|c|}{2014} \\
\hline \multirow{3}{*}{$y_{1}$} & Pooled data set & 9138,00 & 122922207,00 & 4650649,99 & 12627783,91 \\
\hline & Foreign controlled banks & 9138,00 & 122922207,00 & 3527014,89 & 12959409,15 \\
\hline & Banks with domestic capital & 27028,00 & 42725360,00 & 8099948,47 & 10983733,72 \\
\hline \multirow{3}{*}{$y_{2}$} & Pooled data set & 8172,00 & 91841753,00 & 2999479,28 & 8614744,95 \\
\hline & Foreign controlled banks & 8172,00 & 91841753,00 & 2499729,84 & 9216806,11 \\
\hline & Banks with domestic capital & 38186,00 & 27635314,00 & 4533593,84 & 6269070,55 \\
\hline \multicolumn{6}{|c|}{2015} \\
\hline \multirow{3}{*}{$y_{1}$} & Pooled data set & 0,00 & 113725692,00 & 3967891,67 & 10936369,75 \\
\hline & Foreign controlled banks & 0,00 & 113725692,00 & 3169353,20 & 11553770,90 \\
\hline & Banks with domestic capital & 1537,00 & 29486466,00 & 6496596,81 & 8318545,05 \\
\hline \multirow{3}{*}{$y_{2}$} & Pooled data set & 0,00 & 106342198,00 & 3415035,77 & 9818825,37 \\
\hline & Foreign controlled banks & 0,00 & 106342198,00 & 2882611,25 & 10611970,64 \\
\hline & Banks with domestic capital & 44971,00 & 27804171,00 & 5101046,76 & 6538988,60 \\
\hline
\end{tabular}

